\title{
An unusual case of systemic amyloid causing constrictive heart failure
}

\author{
F. A. A. Mohamed Hoesein ${ }^{1}$ M. J. Swaans ${ }^{2}$ L. S. Jiwa ${ }^{3}$ C. A. Seldenrijk ${ }^{3}$ H. W. van Es ${ }^{1}$
}

Published online: 18 August 2016

(c) The Author(s) 2016. This article is available at SpringerLink with Open Access.

\begin{abstract}
A 74-year-old male was analysed for exertional dyspnoea in our outpatient clinic. Cardiac MRI showed diffuse enhancing pericardial soft-tissue (Fig. 1a), but no late gadolinium myocardial enhancement. PET-CT showed the pericardial and peri-renal soft-tissue mass to be calcified, however without FDG uptake. Surgical biopsy of the omentum revealed amyloid depositions fitting with a diagnosis of systemic amyloid. Systemic therapy was started, but the heart failure was progressive and not responding to medical therapy. On repeat cardiac MRI flattening of the ventricular septum during expiration was seen during free breathing (online movie 1). Postmortem macroscopic examinations of the heart and kidney showed extensive peri-renal and pericardial amyloid deposition (Fig. 1b).

Cardiac amyloid is a rare systemic disease ( 6 per million cases). In most cases there is restrictive heart failure because of amyloid depositions. The usual pattern seen on cardiac MRI is late gadolinium enhancement of the entire subendocardial ring. It is very rare for systemic amyloid to present with pericardial amyloid depositions causing severe constrictive heart failure [1-3].
\end{abstract}

Video online The online version of this article (doi: 10.1007/ s12471-016-0890-y) contains a movie, which is available to authorized users.

F. A. A. Mohamed Hoesein

fmohamedhoesein@gmail.com

1 Department of Radiology, St. Antonius Hospital Nieuwegein, Nieuwegein, The Netherlands

2 Department of Cardiology, St. Antonius Hospital Nieuwegein, Nieuwegein, The Netherlands

3 Pathology and DNA, St. Antonius Hospital Nieuwegein, Nieuwegein, The Netherlands
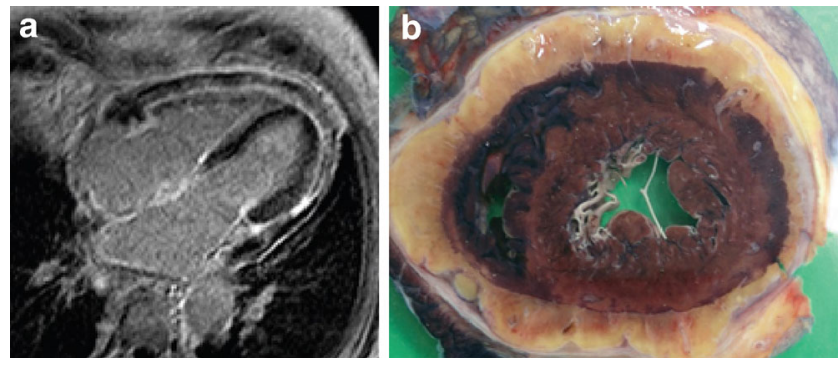

Fig. 1 a Patchy enhancing pericardial soft-tissue on late-gadolinium enhanced MRI, b Macroscopic image of the heart with pericardial amyloid deposition

Conflict of interest F.A.A. Mohamed Hoesein, M.J. Swaans, L.S. Jiwa, C.A. Seldenrijk and H.W. van Es declare that they have no competing interests.

Open Access This article is distributed under the terms of the Creative Commons Attribution 4.0 International License (http:// creativecommons.org/licenses/by/4.0/), which permits unrestricted use, distribution, and reproduction in any medium, provided you give appropriate credit to the original author(s) and the source, provide a link to the Creative Commons license, and indicate if changes were made.

\section{References}

1. Wechalekar AD, Gillmore JD, Hawkins PN. Systemic amyloidosis. Lancet. 2015; doi:10.1016/S0140-6736(15)01274-X.

2. Syed IS, Glockner JF, Feng D, et al. Role of cardiac magnetic resonance imaging in the detection of cardiac amyloidosis. JACC Cardiovasc Imaging. 2010;3:155-64.

3. Banypersad SM, Moon JC, Whelan C, et al. Updates in cardiac amyloidosis: a review. J Am Heart Assoc. 2012;1:e00364. 